Article

\title{
Application Potential Analysis of Enhanced Oil Recovery by Biopolymer-Producing Bacteria and Biosurfactant-Producing Bacteria Compound Flooding
}

\author{
Yongqiang $\mathrm{Bi}^{1, * \mathbb{D}}$, Jianlong $\mathrm{Xiu}^{2}$ and Ting $\mathrm{Ma}^{3}$ \\ 1 School of Mechanical Engineering, Xi'an Aeronautical University, Xi'an 710077, Shaanxi, China \\ 2 PetroChina Research Institute of Petroleum Exploration and Development, Beijing 100083, China; \\ xiujianlong69@petrochina.com.cn \\ 3 College of Life Sciences, Nankai University, Tianjin 300071, China; tingma@nankai.edu.cn \\ * Correspondence: bicheng929@163.com; Tel.: +86-029-84253390
}

Received: 25 October 2019; Accepted: 22 November 2019; Published: 26 November 2019

Featured Application: Biopolymer-producing strain FY-07 is capable of producing bacterial cellulose (BC) under both aerobic and anaerobic conditions, while the biosurfactant-producing strain $\mathrm{WJ}-1$ produces a rhamnolipid, which is a biosurfactant widely used in the oil extraction. The present research envisages the evaluation of the potential of combined flooding of the biopolymer-producing bacteria FY-07 and biosurfactant-producing bacteria WJ-1 for enhancing the oil recovery in heterogeneous reservoirs.

\begin{abstract}
To study the feasibility of polymer-producing bacteria Enterobacter cloacae (E. cloacae) FY-07 and surfactant-producing bacteria Pseudomonas aeruginosa WJ-1 combined profile control and flooding, the compatibility of FY-07 and WJ-1 was evaluated using laboratory experiments. The results showed that the growth and metabolism of WJ-1 was not significantly affected by the FY-07 in the degradation medium, and the surface tension of fermentation broth was reduced from $70 \mathrm{mN} / \mathrm{m}$ to $30 \mathrm{mN} / \mathrm{m}$. FY-07 enhanced the degradation of WJ-1, increasing the ratio of C14- to C15+ from 0.37 to 0.67 . The core-flooding experiments indicated the oil recovery of $17.4 \%$ when both FY- 07 and WJ-1 were injected into the system, as against to $10.4 \%$ and $7.9 \%$ for FY-07 and WJ-1, respectively, when injected alone. The results demonstrate a good compatibility between the FY-07 and WJ-1 strains and highlight the application potential of stain FY-07 and strain WJ-1 compound flooding for enhancing the oil recovery in heterogeneous reservoirs.
\end{abstract}

Keywords: microbial enhanced oil recovery; biopolymer; biosurfactant; compound flooding; potential evaluation

\section{Introduction}

In spite of the development in the traditional primary and secondary recovery methods, two-thirds of the original oil is still left in the reservoir [1,2]. It has become an urgent problem for petroleum scientists and technicians to study the methods to improve the oil recovery and develop efficient substituted techniques for maximizing the exploitation and utilization of existing resources. Chemical enhanced oil recovery (CEOR) methods involve the injection of suitable chemicals such as polymers, surfactants, and alkalis, either individually or in combination, to increase oil production [3-5]. Traditionally, synthetic and non-biodegradable surfactants and polymers were used for improving the oil recovery due to relatively lower costs [6,7]. However, due to stringent environmental restrictions, 
there is a need for the petroleum production and exploration industry to adopt the microbial enhanced oil recovery (MEOR), which is environmentally friendly and cost effective [8]. MEOR is an alternative method of advanced oil recovery that takes the advantage of the ability of the microorganisms to synthesize products (e.g., biosurfactants, biopolymers, biogases, or acids) that are useful for improving oil recovery [9-11].

MEOR mainly improves the oil recovery by increasing the displacement efficiency and the sweep volume of reservoir [12]. Some scholars have screened the different biosurfactant-producing bacteria for improving the oil displacement efficiency $[4,13,14]$, while others used the biopolymer-producing bacteria to improve the sweep efficiency $[8,15,16]$. Qi et al. studied the compatibility between the W5 strains and the weak gel and highlighted the application potential of weak gel-assisted microbial flooding [17]. Dhanarajan et al. studied the combined influence of the biosurfactant and biopolymers on the solubilization and mobilization of oil from the reservoir [18].

Biopolymer-producing strain FY-07 is capable of producing bacterial cellulose (BC) under both aerobic and anaerobic conditions [19], while the biosurfactant-producing strain WJ-1 produces a rhamnolipid, which is a biosurfactant widely used in oil extraction [20]. The present research envisages the evaluation of the potential of combined flooding of the biopolymer-producing bacteria FY-07 and biosurfactant-producing bacteria WJ-1 through systematic experimental investigation.

\section{Materials and Methods}

\subsection{Microorganisms and Culture Conditions}

In this study, the biopolymer-producing microorganism Enterobacter cloacae (E. cloacae) FY-07 was isolated from the oilfield produced water in Jilin oil field, China. Another biosurfactant-producing microorganism identified as Pseudomonas aeruginosa WJ-1 was isolated from the oilfield produced water in Menggulin oil field, China.

The two strains were cultured in Luria-Betrani(LB) medium $(10 \mathrm{~g} / \mathrm{L}$ peptone, $5 \mathrm{~g} / \mathrm{L}$ yeast extract, $10 \mathrm{~g} / \mathrm{L} \mathrm{NaCl}$ ) and incubated at $180 \mathrm{rpm}$ at $37{ }^{\circ} \mathrm{C}$ for $16 \sim 20 \mathrm{~h}$, and then inoculated $2 \%(v / v)$ into the following fermentation medium. Crude oil degradation medium $(\mathrm{g} / \mathrm{L})$ : crude oil (8.0), $\mathrm{NaNO}_{3}$ (1.0), $\mathrm{K}_{2} \mathrm{HPO}_{4}$ (1.0), $\mathrm{NaH}_{2} \mathrm{PO}_{4}$ (1.0), $\mathrm{MgSO}_{4} \cdot 7 \mathrm{H}_{2} \mathrm{O}(0.5), \mathrm{NaCl}(1.0) \mathrm{FeSO}_{4} \cdot 7 \mathrm{H}_{2} \mathrm{O}(0.01$, $\mathrm{CaCl}_{2}(0.01), \mathrm{ZnCl}_{2}(0.01), \mathrm{Na}_{2} \mathrm{MoO}_{4} \cdot 2 \mathrm{H}_{2} \mathrm{O}(0.01), \mathrm{pH}$ 7.2 7.5. Polymer-producing medium: $\mathrm{KNO}_{3}(1.0)$, glucose (30.0), $\mathrm{Na}_{2} \mathrm{HPO}_{4} \cdot 12 \mathrm{H}_{2} \mathrm{O}$ (1.5), $\mathrm{MgSO}_{4} \cdot 7 \mathrm{H}_{2} \mathrm{O}(0.25), \mathrm{MnCl}_{2}$ (0.20), $\mathrm{Na}_{2} \mathrm{SO}_{4}$ (0.32), yeast (0.10), peptone (2.0), $\mathrm{pH} 7.0 \sim 7.2$.

\subsection{Oil and Water Samples}

The crude oil and formation water used in the experiments were collected from the oil-producing wells of the Luliang block in the Xinjiang Oilfield (China National Petroleum Corporation, Sinkiang, China) with an average temperature of $34^{\circ} \mathrm{C}$.

\subsection{Detection of Growth and Metabolism of Different Strains in Crude Oil Degradation Medium}

The strains WJ-1, FY-07, and mixed bacteria (WJ-1: FY-07 = 1:1) were inoculated into crude oil degradation medium with $2 \%$ inoculation quantity, cultured at $180 \mathrm{r} / \mathrm{min}$ at $34{ }^{\circ} \mathrm{C}$. Samples were collected regularly. Surface tension values were measured using the surface tensiometer FTA1000B (First Ten Angstroms, Portsmouth, Virginia, US), and the number of bacteria was determined by plate counting method based on different morphology of bacteria.

\subsection{Detection of Growth of Different Strains in Polymer-Producing Medium}

Strain FY-07 and mixed bacteria (WJ-1: FY-07 = 1:1) were inoculated into crude oil degradation medium with $2 \%$ inoculation quantity and cultured at $34{ }^{\circ} \mathrm{C}$ under static conditions. Samples were collected regularly, and the number of bacteria was determined by the plate counting method based on the different morphology of bacteria. 


\subsection{Analysis of Content and Group Component of Degraded Petroleum}

After the cultivation, the degraded petroleum was treated by WJ-1, FY-07, and mixed bacteria WJ-1 and FY-07, centrifuged ( $8000 \mathrm{r} / \mathrm{min})$ at $4{ }^{\circ} \mathrm{C}$, and the upper crude oil without water was obtained and subjected to the following analysis. The crude oil before and after degradation was immersed in excessive petroleum ether for $24 \mathrm{~h}$ and filtered to obtain the insoluble gum and asphalt, and then quantified. Saturated hydrocarbons, aromatic hydrocarbons, and non-hydrocarbons in crude oil were separated by a silica gel-Alumina mixed column and elution with n-hexane, n-hexane: dichloromethane mixture $(1: 1, v / v)$, an ethanol and trichloroethane mixture $(1: 1, v / v)[17,21]$, and the change in oil composition resulting from microbial degradation was assessed.

\subsection{Gas Chromatographic Analysis of Saturated Hydrocarbons in Degraded Petroleum}

The saturated hydrocarbon composition of the degraded petroleum was determined by the gas chromatography (GC) method. The oil samples were first extracted by chloroform and then measured using HP6890 GC (Agilent, Santa Clara, California, US), equipped with a PONA quartz capillary column $(30 \mathrm{~m} \times 0.2 \mathrm{~mm} \times 0.2 \mu \mathrm{m})$. Split injections were conducted using nitrogen as a carrier gas. The column temperature was raised from $50{ }^{\circ} \mathrm{C}$ to $310^{\circ} \mathrm{C}$ at a rate of $8{ }^{\circ} \mathrm{C} / \mathrm{min}$. An interface temperature of $310^{\circ} \mathrm{C}$ and an ion source temperature of $320^{\circ} \mathrm{C}$ were utilized [22].

\subsection{Physical Simulation Experiment of Oil Displacement}

The potential applications of microbial enhanced oil recovery of WJ-1, FY-07, and compound bacteria of WJ-1 and FY-07 were evaluated by core flooding experiments. Four three-layer heterogeneous cement cores were used in the experiment. The core parameters are shown in Table 1, and the schematic diagram of the experimental setup for the core flooding experiments is shown in Figure 1. Initially, the heterogeneous cemented cores were saturated with formation water after vacuum pumping and flooded with dewatered and degassed crude oil to establish the original oil saturation. Subsequently, the heterogeneous cemented cores were flooded with formation water until the water fraction of the effluent was higher than $98 \%$. Following the first water flooding, No. 1 core was the control group and was incubated at $34{ }^{\circ} \mathrm{C}$ for seven days. Core 2 and Core 3 were used to evaluate the displacement efficiency of WJ-1 and FY-07, respectively. Among them, Core 2 was injected with degradation medium inoculated with $2 \% \mathrm{WJ}-1$ seed solution and cultured at $34{ }^{\circ} \mathrm{C}$ for seven days. Core 3 was injected with polymer-producing medium inoculated with $2 \%$ FY-07 seed solution and incubated at $34{ }^{\circ} \mathrm{C}$ for seven days. Core 4 was used to evaluate the composite flooding effect of FY-07 and WJ-1, which was first infused with $0.5 \mathrm{pv}$ FY- 07 at $34{ }^{\circ} \mathrm{C}$ for seven days, then $0.5 \mathrm{pv}$ WJ-1, and cultured further at $34{ }^{\circ} \mathrm{C}$ for seven days. Finally, formation brine flooding was performed again, until no further oil was observed. During the experiment, the injection rate was set to $1.0 \mathrm{~mL} / \mathrm{min}$.

Table 1. Parameters of heterogeneous cores.

\begin{tabular}{cccc}
\hline No. & Tested Project & Length $\times$ Width $\times$ Height $(\mathbf{c m} \times \mathbf{c m} \times \mathbf{c m})$ & Permeability $\left(\mathbf{1 0}^{-\mathbf{3}} \boldsymbol{\mu m}^{\mathbf{2}}\right)$ \\
\hline 1 & Control & $30.0 \times 4.5 \times 4.5$ & 1138 \\
2 & WJ-1 & $30.0 \times 4.5 \times 4.5$ & 1118 \\
3 & FY-07 & $30.0 \times 4.5 \times 4.5$ & 1048 \\
4 & FY-07+WJ-1 & $30.0 \times 4.5 \times 4.5$ & 1092 \\
\hline
\end{tabular}




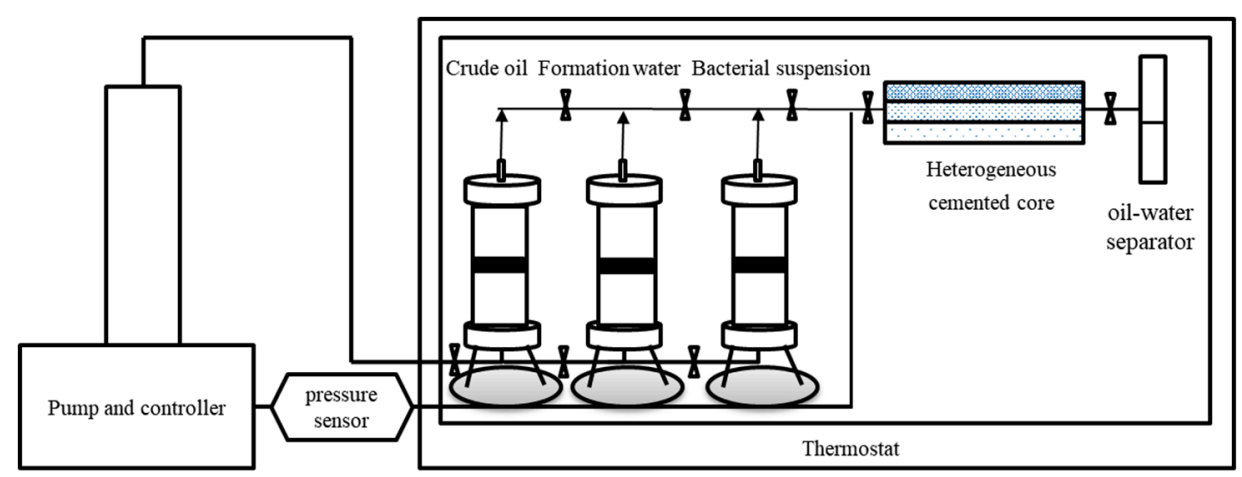

Figure 1. Schematic diagram of the experimental setup for core flooding experiments.

\section{Results and Discussion}

\subsection{Effect of FY-07 on the Growth and Metabolism of WJ-1}

To study the feasibility of compound flooding by FY-07 and WJ-1 strains, the strains WJ-1, FY-07, and the mixed bacteria (WJ-1: FY-07 = 1:1) culture experiment was carried out. The growth of these strains is shown in Figure 2. The growth of strain WJ-1 is divided into four stages-the lag phase, exponential phase (log phase), stationary phase, and death phase. WJ-1 exhibited the same lag phase, $\log$ phase, and stable phase under the condition of single culture and mixed culture. This indicated that the growth of the two strains had no effect on each other under the condition of adequate nutrition. However, under the mixed culture condition of FY-07, the decline period of WJ-1 was advanced because the nutrient consumption was exhausted in the late stage of strain growth, and there was a competition for nutrients between the strains.

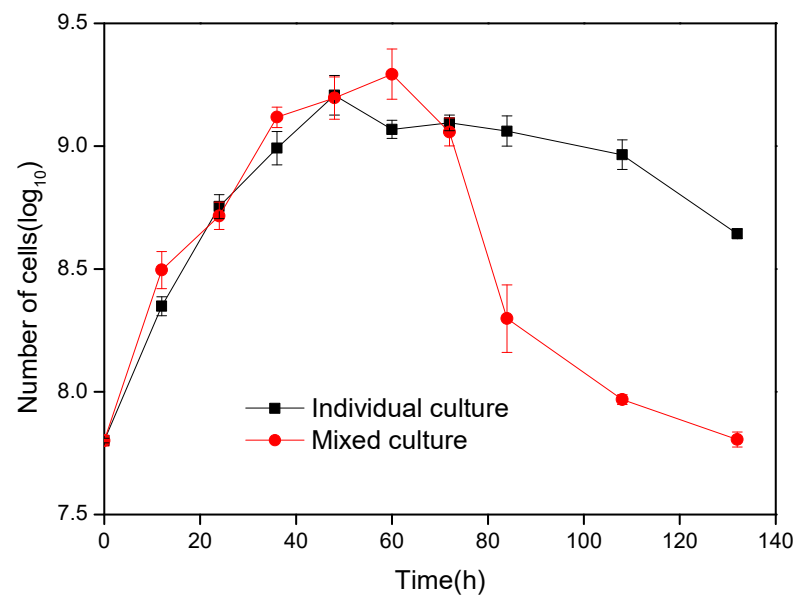

Figure 2. Growth curve of Pseudomonas aeruginosa WJ-1 with and without FY-07.

The growth of the strain reduced the surface tension of the fermentation broth due to formation of the metabolizing surfactant. Therefore, the metabolic status of strains can be reflected by analyzing the change of surface tension. The reduction of surface tension by growth and metabolism of experimental strains is shown in Figure 3. Under the condition of degradation medium, WJ-1, FY-07, mixed WJ-1 and FY-07 bacteria reduced the surface tension to $30 \mathrm{mN} / \mathrm{m}$ from $70 \mathrm{mN} / \mathrm{m}$. However, the time for WJ-1 to reach the minimum surface tension was basically the same under the condition of single culture and mixed culture, which was earlier than that of FY-07. This shows that both WJ-1 and FY-07 produced some surfactant to reduce the surface tension, but WJ-1 produced the biosurfactant faster than FY-07. It mainly emulsified the crude oil due to the biosurfactant produced by the WJ-1 metabolism, while FY-07 mainly relied on the biopolymer produced to form plugging control. The presence of strain FY-07 did not reduce the emulsification of strain WJ-1. 


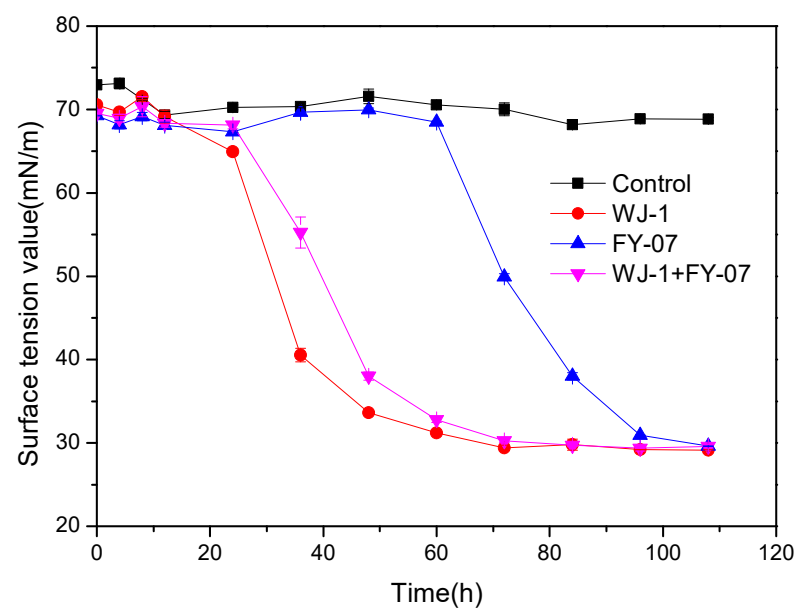

Figure 3. Surface tension curve under the action of different bacteria.

\subsection{Effect of the Strain WJ-1 on Growth of Strain FY-07}

To analyse the effect of WJ-1 on the growth and metabolism of FY-07, the growth of the strain in the polymer-producing medium was determined. Figure 4 shows that the concentration of FY-07 in mixed culture conditions with WJ-1 was higher than that of the culture alone, and the decline period was slightly earlier. Therefore, the existence of WJ-1 did not affect the growth and metabolism of FY-07 to produce the biopolymers but played a certain role in promoting the growth and metabolism of FY-07. Furthermore, the strain grew faster in the polymer-producing medium than in the crude oil degradation medium. Therefore, in compound profile control and flooding, the action time of strain WJ-1 was longer than that of strain FY-07.

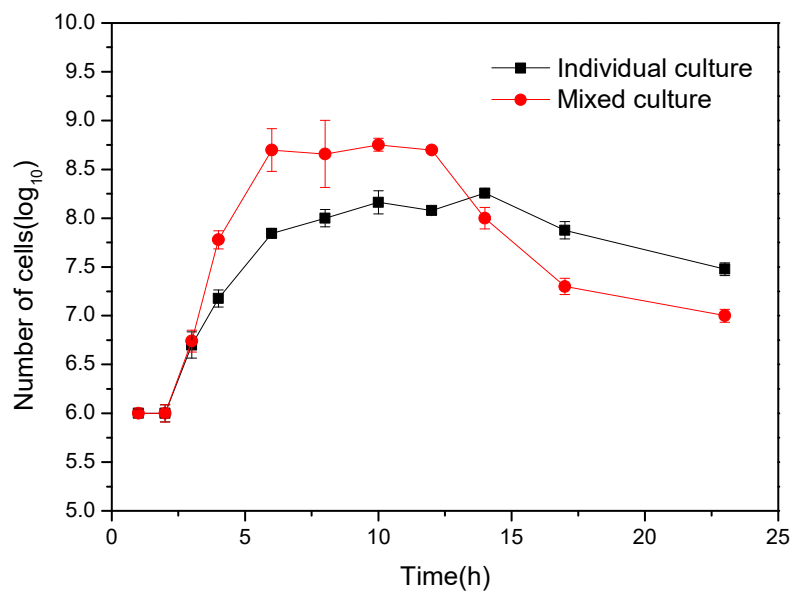

Figure 4. Growth curve of E. cloacae FY-07 without and with Pseudomonas aeruginosa WJ-1.

\subsection{Effect of Strain FY-07 on Degradation of Strain WJ-1}

After the degradation by WJ-1, FY-07 and the mixture of the two strains for 7 days, the relative contents of the different components of the crude oil (saturated hydrocarbons, aromatic hydrocarbons, non-hydrocarbon, and asphaltene) before and after degradation are shown in Figure 5. Luliang oil without microbial treatment consisted of $71.62 \%$ oil saturated hydrocarbons, $9.91 \%$ aromatic hydrocarbons, $13.84 \%$ non-hydrocarbons, and $4.63 \%$ asphaltene. After degradation by WJ-1, the content of the saturates decreased to $70.40 \%$, while the proportions of aromatics, non-hydrocarbon, and asphaltene increased to $10.33 \%, 14.03 \%$, and $5.23 \%$, respectively. This indicates that WJ-1 mainly degraded the saturated hydrocarbons. After degradation by FY-07, the contents of the saturates and aromatics increased to $73.43 \%$ and $10.72 \%$, respectively. In contrast, the proportions of the 
non-hydrocarbon and asphaltene increased to $14.03 \%$ and $5.23 \%$, which indicates that WJ-1 mainly degraded the saturated hydrocarbons. When crude oil passes through the combined action of WJ-1 and FY-07, the proportion of the saturates and aromatics reduced to $66.07 \%$ than WJ-1, which indicates that FY-07 improved the degradation of saturated hydrocarbons by WJ-1.

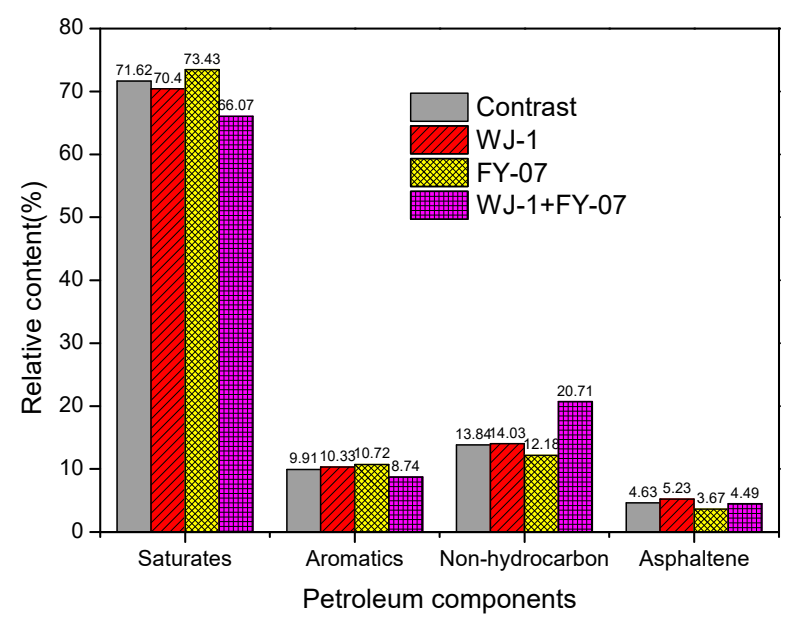

Figure 5. Contents of different carbon numbers of crude oil before and after microbial treatment.

The compositions of the saturated hydrocarbons were analyzed by GC method [19]. A relative wide range of alkanes (C8-C45) were utilized by the strains according to GC analysis (Figure 6). The degradation of FY-07 was not obvious, and the degradation of WJ-1 and complex bacteria was obvious. The degradation was mainly reflected in the decrease of $\mathrm{C} 15+$ content and the increase of C14- content (Figure 7). By calculating the ratio of $\mathrm{C} 14-$ to $\mathrm{C} 15+$, it was found that the ratio untreated crude oil was 0.17 , and for WJ, FY-07, and WJ-1 and FY-07 mixture was $0.37,0.15$, and 0.67 , respectively. Obviously, FY-07 did not degrade the crude oil, but it promoted the degradation of WJ-1.
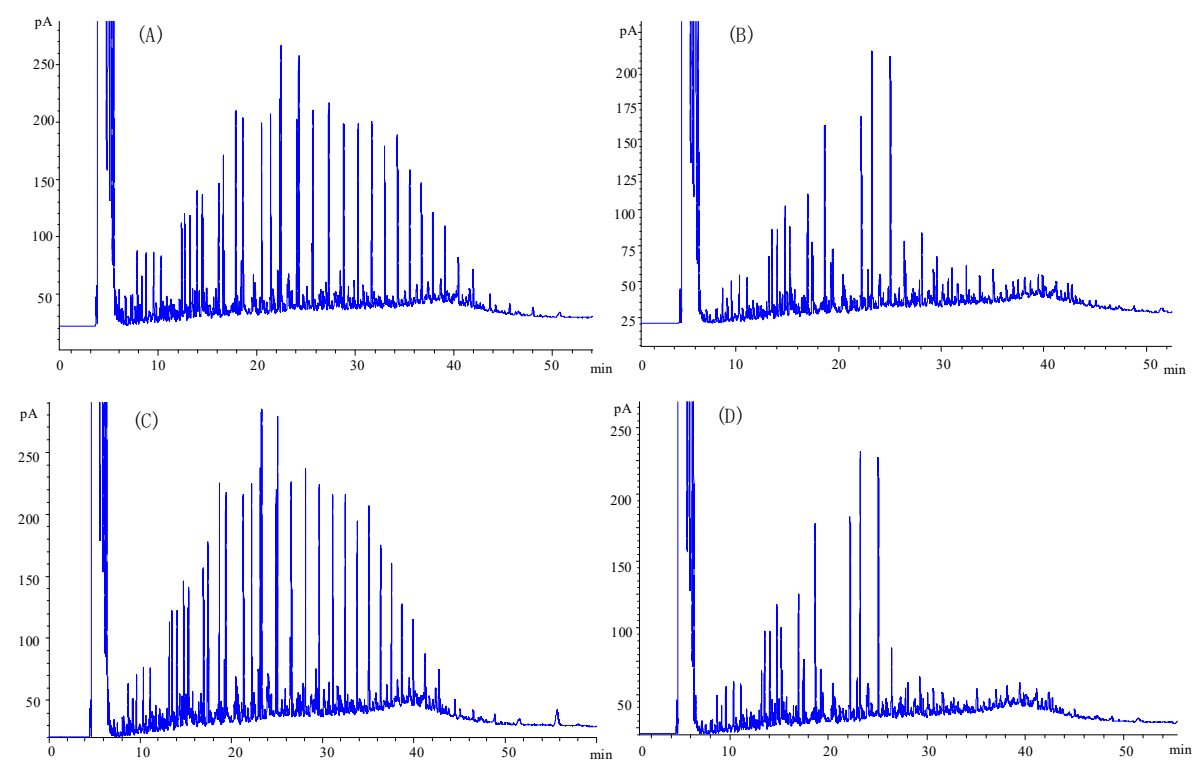

Figure 6. Gas chromatography (GC) analysis of n-alkane compositions of crude oil after treatments of strains. (A) Control; (B) WJ-1; (C) FY-07; (D) WJ-1 + FY-07. 


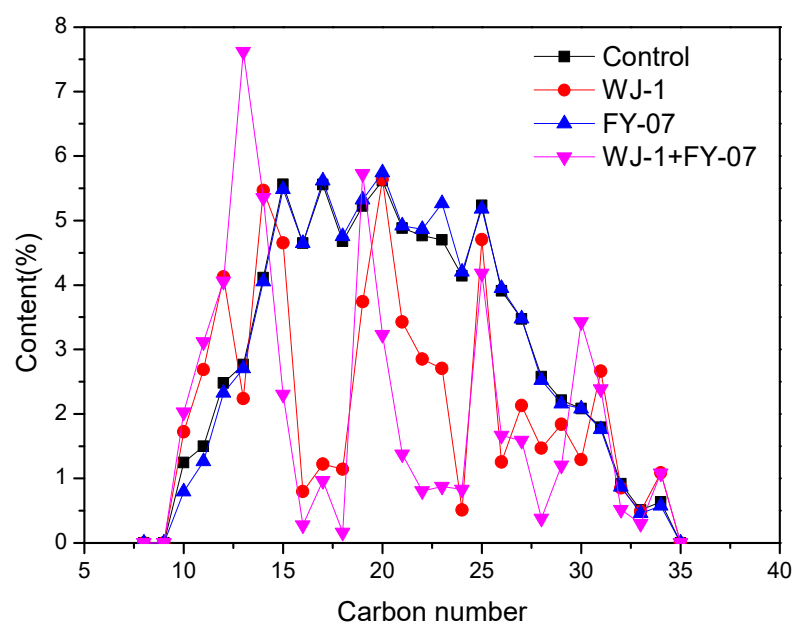

Figure 7. Contents of different carbon number of crude oils before and after microbial treatment.

\subsection{Comparative Analysis of the Ability of Composite Strains to Improve Oil Recovery}

The ultimate goal of MEOR is to enhance the oil recovery or the oil production rate. As shown in Table 2, WJ-1, FY-07, and the mixed bacteria of WJ-1 and FY-07 greatly improved the oil recovery compared to the control sample. After the control sample was stationary for 10 days, the subsequent water flooding enhanced the oil recovery by 3.9\%, which was due to the redistribution of the oil and water after a period of stationary storage, and the re-entry of the crude oil from low permeability layers into the high permeability layers, and further recovery in subsequent water flooding. FY-07 enhanced oil recovery by $10.4 \%$. This is because the biopolymer produced by the metabolism of the strain formed a plugging of the high-permeability layer, which further improved the recovery of crude oil in the low-permeability layer. WJ-1 enhanced the oil recovery by $7.9 \%$, since the strain degraded the degraded high-carbon chain crude oil into low-carbon chain crude oil, improved the fluidity of crude oil, and the metabolized biological surfactant emulsified the crude oil. The composite flooding of FY-07 and WJ-1 increased oil recovery by $17.4 \%$, which was significantly higher than the individual effects of FY-07 and WJ-1. This is because, after water flooding, most of the crude oil existed in the low permeability layer. First, FY-07 was injected to block the high permeability layer 12 . Then, the injected WJ-1 entered the low permeability layer in large quantities and acted on most of the crude oil. Therefore, it exhibited a synergistic effect on the oil displacement and has a certain application prospect for the efficient development of heterogeneous reservoirs.

Table 2. Results of the core-flooding tests.

\begin{tabular}{|c|c|c|c|c|c|c|}
\hline \multirow{2}{*}{ No. } & \multirow{2}{*}{ Tested Slug } & \multirow{2}{*}{ Porosity (\%) } & \multirow{2}{*}{$\begin{array}{c}\text { Initial Oil } \\
\text { Saturation (\%) }\end{array}$} & \multicolumn{3}{|c|}{ Oil Recovery (\%) } \\
\hline & & & & $\begin{array}{l}\text { Water Flooding } \\
\text { Oil Recovery }\end{array}$ & $\begin{array}{c}\text { Final } \\
\text { Recovery }\end{array}$ & $\begin{array}{c}\text { EOR } \\
\text { Efficiency }\end{array}$ \\
\hline 1 & Control & 28.2 & 78.1 & 18.4 & 21.3 & 2.9 \\
\hline 2 & FY-07 & 27.5 & 78.7 & 21.2 & 31.6 & 10.4 \\
\hline 3 & WJ-1 & 28.0 & 77.9 & 18.6 & 26.5 & 7.9 \\
\hline 4 & FY-07+WJ-1 & 28.4 & 77.4 & 20.9 & 38.3 & 17.4 \\
\hline
\end{tabular}

\section{Conclusions}

In the present study, it was found that FY-07 did not significantly inhibit the growth and metabolism of WJ-1 under sufficient nutrition conditions but improved the ability of WJ-1 to degrade the high carbon chain crude oil. In fact, WJ-1 promoted the growth and metabolism of FY-07 to some extent. The results indicate that WJ-1 and FY-07 exhibited a good compatibility. Physical simulation oil displacement experiments show that WJ-1 and FY-07 combined flooding improved the oil recovery 
by $17.4 \%$, which was higher than the individual effect of the two strains. Therefore, compound flooding with the polymer-producing bacteria FY-07 and the surfactant-producing bacteria WJ-1 has a good application prospects for enhancing the oil recovery in heterogeneous reservoirs.

Author Contributions: Y.B., J.X., and T.M. designed and discussed the experiment; T.M. provided the strain E. cloacae FY-07; Y.B. conducted the experiment; Y.B. and J.X. analyzed and discussed the results; Y.B. wrote the paper; T.M. gave the help and suggestion in the revised manuscript.

Funding: This research was supported by the National Natural Science Foundation of China (NO.2018JQ1067), the Natural Science Basic Research Program of Shaanxi Province (NO.2019JM-396) and the Research Foundation Project of Xi'an Aeronautical University (NO.2018KY0101). We thank the support from CNPC Key Laboratory of Enhanced Oil Recovery.

Conflicts of Interest: The authors declare no conflict of interest.

\section{References}

1. Brown, L.R. Microbial enhanced oil recovery (MEOR). Curr. Opin. Microbiol. 2010, 13, 316-320. [CrossRef]

2. Maugeri, L. Squeezing more oil from the ground. Sci. Am. 2009, 301, 56-63. [CrossRef] [PubMed]

3. Negin, C.; Ali, S.; Xie, Q. Most common surfactants employed in chemical enhanced oil recovery. Petroleum 2017, 3, 197-211. [CrossRef]

4. Hadia, N.J.; Ottenheim, C.; Li, S.; Hua, N.Q.; Stubbs, L.P.; Lau, H.C. Experimental investigation of biosurfactant mixtures of surfactin produced by Bacillus Subtilis for EOR application. Fuel 2019, 251, 789-799. [CrossRef]

5. Mishra, G.; Mittal, N.; Sharma, A. Multifunctional mesoporous carbon capsules and their robust coatings for encapsulation of actives: Antimicrobial and anti-bioadhesion functions. ACS Appl. Mater. Interfaces 2016, 9, 19371-19379. [CrossRef] [PubMed]

6. Mittal, N.; Ansari, F.; Gowda, V.K.; Brouzet, C.; Chen, P.; Larsson, P.T.; Roth, S.V.; Lundell, F.; Wagberg, L.; Kotov, N.A. Multiscale control of nanocellulose assembly: Transferring remarkable nanoscale fibril mechanics to macroscale fibers. ACS Nano 2018, 12, 6378-6388. [CrossRef]

7. Mohanty, A.; Misra, M.a.; Hinrichsen, G. Biofibres, biodegradable polymers and biocomposites: An overview. Macromol. Mater. Eng. 2000, 276, 1-24. [CrossRef]

8. Sun, S.; Luo, Y.; Cao, S.; Li, W.; Zhang, Z.; Jiang, L.; Dong, H.; Yu, L.; Wu, W.-M. Construction and evaluation of an exopolysaccharide-producing engineered bacterial strain by protoplast fusion for microbial enhanced oil recovery. Bioresour. Technol. 2013, 144, 44-49. [CrossRef]

9. Mittal, N.; Jansson, R.; Widhe, M.; Benselfelt, T.; Håkansson, K.M.; Lundell, F.; Hedhammar, M.; Söderberg, L.D. Ultrastrong and bioactive nanostructured bio-based composites. ACS Nano 2017, 11, 5148-5159. [CrossRef]

10. Patel, J.; Borgohain, S.; Kumar, M.; Rangarajan, V.; Somasundaran, P.; Sen, R. Recent developments in microbial enhanced oil recovery. Renew. Sustain. Energy Rev. 2015, 52, 1539-1558. [CrossRef]

11. Joy, S.; Rahman, P.K.; Sharma, S. Biosurfactant production and concomitant hydrocarbon degradation potentials of bacteria isolated from extreme and hydrocarbon contaminated environments. Chem. Eng. J. 2017, 317, 232-241. [CrossRef]

12. Muggeridge, A.; Cockin, A.; Webb, K.; Frampton, H.; Collins, I.; Moulds, T.; Salino, P. Recovery rates, enhanced oil recovery and technological limits. Philos. Trans. R. Soc. A Math. Phys. Eng. Sci. 2014, 372, 20120320. [CrossRef] [PubMed]

13. Xia, W.; Luo, Z.; Dong, H.; Yu, L. Studies of biosurfactant for microbial enhanced oil recovery by using bacteria isolated from the formation water of a petroleum reservoir. Pet. Sci. Technol. 2013, 31, 2311-2317. [CrossRef]

14. Cui, Q.; Sun, S.; Luo, Y.; Yu, L.; Zhang, Z. Comparison of in-situ and ex-situ microbial enhanced oil recovery by strain Pseudomonas aeruginosa WJ-1 in laboratory sand-pack columns. Pet. Sci. Technol. 2017, 35, 2044-2050. [CrossRef]

15. Bi, Y.; Yu, L.; Huang, L.; Ma, T.; Xiu, J.; Yi, L. Microscopic profile control mechanism and potential application of the biopolymer-producing strain FY-07 for microbial enhanced oil recovery. Pet. Sci. Technol. 2016, 34, 1952-1957. [CrossRef]

16. Couto, M.R.; Gudiña, E.J.; Ferreira, D.; Teixeira, J.A.; Rodrigues, L.R. The biopolymer produced by Rhizobium viscosum CECT 908 is a promising agent for application in microbial enhanced oil recovery. New Biotechnol. 2019, 49, 144-150. [CrossRef] 
17. Qi, Y.-B.; Zheng, C.-G.; Lv, C.-Y.; Lun, Z.-M.; Ma, T. Compatibility between weak gel and microorganisms in weak gel-assisted microbial enhanced oil recovery. J. Biosci. Bioeng. 2018, 126, 235-240. [CrossRef]

18. Dhanarajan, G.; Rangarajan, V.; Bandi, C.; Dixit, A.; Das, S.; Ale, K.; Sen, R. Biosurfactant-biopolymer driven microbial enhanced oil recovery (MEOR) and its optimization by an ANN-GA hybrid technique. J. Biotechnol. 2017, 256, 46. [CrossRef]

19. Ma, T.; Ji, K.; Wang, W.; Wang, J.; Li, Z.; Ran, H.; Liu, B.; Li, G. Cellulose synthesized by Enterobacter sp. FY-07 under aerobic and anaerobic conditions. Bioresour. Techno. 2012, 126, 18-23. [CrossRef]

20. Xia, W.-J.; Luo, Z.-b.; Dong, H.-P.; Yu, L.; Cui, Q.-F.; Bi, Y.-Q. Synthesis, characterization, and oil recovery application of biosurfactant produced by indigenous Pseudomonas aeruginosa WJ-1 using waste vegetable oils. Appl. Biochem. Biotechnol. 2012, 166, 1148-1166. [CrossRef]

21. Ji, S.; Zhou, Y.; Ge, D.; Chen, K.; Wang, Z. Synergism of Hydrogen and Oil Composition in Noncatalytic Upgrading of Petroleum Residues. Pet. Sci. Technol. 2014, 32, 2903-2910. [CrossRef]

22. Zheng, C.; Li, Y.; Huang, L.; Xiu, J.; Huang, Z. Investigation of a hydrocarbon-degrading strain, Rhodococcus ruber Z25, for the potential of microbial enhanced oil recovery. J. Pet. Sci. Eng. 2012, 81, 49-56. [CrossRef]

(C) 2019 by the authors. Licensee MDPI, Basel, Switzerland. This article is an open access article distributed under the terms and conditions of the Creative Commons Attribution (CC BY) license (http://creativecommons.org/licenses/by/4.0/). 